\title{
Słowo wstępne: W obliczu nadchodzącej fali reform szkolnictwa wyższego w Polsce. Argumentacja i wizja wspierająca najważniejsze kierunki zmian
}

Chcielibyśmy przypomnieć tu krótko kilka wybranych myśli dotyczących reform szkolnictwa wyższego w Polsce zawartych w tekstach w tym i poprzednim numerze Nauki i Szkolnictwa Wyższego (oraz w kilku najnowszych pracach rozproszonych, zob. bibliografię). Ponieważ, jak się wydaje, nowa fala reform właśnie nadciąga, zakładamy, że warto te myśli wyłożyć w jednym miejscu.

Polska zrobiła w obszarze reform w latach 2009-2011 pierwsze kroki w kierunku, na który patrzymy bardzo życzliwie. Jednak pierwsze kroki wymagają kroków kolejnych - bardziej stanowczych i bardziej skoordynowanych, opartych na fundamencie zmian już wprowadzanych w życie - którym będzie towarzyszyć przekonująca wizja przyszłości, a także adekwatne do skali przewidywanych zmian publiczne nakłady finansowe.

Wizja jest niezbędna. Wspólnota akademicka, a przede wszystkim jej najmłodsze pokolenie, musi wiedzieć, na jakich podstawach ma budować swoją akademicką przyszłość i czy jest w stanie się w niej odnaleźć. Warto jasno powiedzieć, że z czasem pojawi się bardziej zróżnicowany system instytucji szkolnictwa wyższego, o różnych możliwościach i różnych zadaniach w różnych miejscach, realizujących różne misje i oferujących różne możliwości awansowe i finansowe. Warto powiedzieć, że niezbędne - ale i możliwe - będą pionowe migracje w ramach różnicującego się systemu w zależności od indywidualnych zdolności, umiejętności, pracowitości, a przede wszystkim mierzalnych osiągnięć naukowych. Należy także przypomnieć, że profesja akademicka nie daje równych szans wszystkim, ponieważ talenty naukowe w ramach wspólnoty akademickiej nie rozkładają się równo, ale z pewnością daje duże szanse najzdolniejszym; że w najlepszych ośrodkach naukowy wymiar kariery akademickiej, tak jak w świecie zachodnim, jest najważniejszy, 
a wszystkie pozostałe są tylko jego tłem; że z czasem wzorce pracy akademickiej i wzorce akademickich zarobków - w wybranych miejscach i dla wybranych grup badaczy - będą przypominać wzorce znane z najlepszych systemów zachodnich; i wreszcie, że w tych wybranych miejscach (zwanych uniwersytetami badawczymi czy flagowymi) uprawianie nauki nie będzie jednostkowym, częściowo niezrozumiałym i częściowo jedynie tolerowanym, hobby.

Taka wizja jest w stanie powstrzymać ucieczkę najzdolniejszych umysłów albo od nauki w ogóle, albo od nauki akademickiej uprawianej w Polsce. Wierzymy, że jest ona możliwa, ponieważ od półtorej dekady szczegółowo śledzimy konstruowanie różnych jej elementów w różnych częściach Europy. Widzimy, jak sprawdza się w praktyce akademickiej, a interesuje nas przede wszystkim to, co się sprawdza.

Stopniowe zmiany zachowań akademickich muszą iść w parze ze stopniowymi zmianami w akademickich przekonaniach, a przekonania kształtują się długo i w związku z tym równie długo się zmieniają. Na ich zmianę wpływają zarówno transformacje zarządzania i organizacji uczelni, jak i transformacje ich finansowania. Polskie reformy ciągle jeszcze nieśmiało wprowadzają zmiany w obydwu obszarach, jednak stopniowe zwiększanie nakładów na badania naukowe i kierowanie ich na różne aspekty umiędzynarodowienia w badaniach może zatrzymać proces stopniowego oddalania się polskiej nauki od akademickich centrów (w stronę akademickich peryferii) w Europie. Zatrzymanie tego niebezpiecznego procesu wciąż jest jeszcze możliwe, ale perspektywa stopniowej konsolidacji krajowego i międzynarodowego finansowania nauki europejskiej (w mniej więcej 50 najlepszych ośrodkach akademickich) czyni go jeszcze trudniejszym niż w poprzednich latach. Rosnąca izolacja międzynarodowa polskiej wspólnoty akademickiej w globalnych i europejskich kanałach transmisji wiedzy (publikacje) oraz w europejskich kanałach transmisji zasobów finansowych (międzynarodowe granty badawcze, zwłaszcza z European Research Council), które są zarazem kanałami transmisji prestiżu w nauce, wymaga skoordynowanych działań na poziomie państwa. Najlepszą (i sprawdzoną w Europie) drogą do intensyfikacji obecności naukowej Polski w świecie jest większe umiędzynarodowienie polskich badań naukowych. Diagnoza prowadząca do powstania pakietu reform z lat 2009-2011 została postawiona słusznie, dobrze zostały również wskazane nowe mechanizmy instytucjonalne.

Jednym z zadań reform w Polsce jest stopniowa zmiana przekonań akademickich (np. w stronę koncentracji na współpracy międzynarodowej w badaniach naukowych w najlepszych ośrodkach) i akademickich zachowań (np. w stronę szerszego publikowania w międzynarodowym obiegu naukowym), a jeszcze bardziej przekonań rodzących akademickie zachowania. Podtrzymywanie mitu o historycznej wyjątkowości najbardziej prestiżowych polskich uniwersytetów w kontekście aktualnych reform uniwersytetów w Europie oraz mitu o możliwości ich niskokosztowego, a zarazem produktywnego funkcjonowania badawczego jest 
w dłuższej perspektywie dla tych instytucji zabójcze. Koncepcja oszczędnościowych uniwersytetów badawczych (budget research universities, analogicznie do budget airlines) niesie duże niebezpieczeństwa na przyszłość i nie została jak dotąd wprowadzona w życie w żadnym kraju zachodnim o dużym potencjale naukowym i wysokich naukowych aspiracjach. Choćby z tego powodu chcielibyśmy, aby nie rozprzestrzeniała się $\mathrm{w}$ Polsce.

Na razie w ramach ostatniej fali reform skupiamy się na sposobach dystrybucji środków przeznaczonych na badania naukowe - podział coraz silniej opiera się na quasi-rynkowej konkurencji, zgodnie z najnowszymi trendami europejskimi, wychodzącymi od konstatacji nadmiaru chętnych starających się o rosnące, ale niewystarczające środki na badania. Natomiast niemal niezmieniony pozostaje drugi element architektoniki finansowania badań naukowych - poziom publicznych nakładów (pomijając unijne fundusze strukturalne). Skuteczne reformy nie mogą skupiać się na pierwszym elemencie, pomijając drugi - choć, rzecz jasna, pierwszy jest warunkiem drugiego. A wyjątkowo wrażliwym, bo kosztownym obszarem jest umiędzynarodowienie badań naukowych, które przy obecnym poziomie finansowania jest - w wyraźnie większej skali - niezwykle trudne. Dzisiejszy poziom finansowania nauki, również $\mathrm{w}$ ramach indywidualnych grantów badawczych, nie umożliwia prowadzenia współpracy międzynarodowej o dużej intensywności. Na dłuższą metę - a procesy relatywnej izolacji międzynarodowej trwają już ponad ćwierć wieku - niedofinansowanie badań naukowych oddziela polską naukę coraz grubszym murem od nauki europejskiej. Drobne wyłomy w tym murze, nieliczne wyjątki potwierdzające regułę, nie zmieniają całościowego obrazu, w którym ani młoda kadra, ani kadra starsza w najlepszych miejscach nie ma finansowych możliwości, aby stawać się coraz bardziej umiędzynarodowioną.

Uważamy, że nie pomogą drobne korekty - niezbędna jest zmiana nastawienia państwa, które od etapu wprowadzania konkurencyjności do systemu powinno przejść do etapu wyższych publicznych nakładów, zwłaszcza na badania podstawowe.

Groźne dla Polski może być dość powszechne przekonanie, że nauka może funkcjonować w ramach ostrego podziału akademickich ról i zadan - z jednej strony jest ogromna część kadry pozbawiona woli i/lub możliwości prowadzenia badań naukowych, a z drugiej - mniejszość dysponująca i wolą, i możliwościami. Taki podział powoduje bowiem rosnące przekonanie zachodniej wspólnoty badawczej, że polska nauka nie jest atrakcyjnym partnerem jako całość. Wydzielenie uczelni badawczych jest dobrym krokiem pokazującym wybrane miejsca, które mogą być atrakcyjne dla współpracy naukowej. Po upływie ćwierćwiecza od upadku komunizmu wszelkie argumenty historyczne przestają mieć znaczenie - liczy się dzisiejsze miejsce Polski w europejskich i globalnych kanałach dystrybucji wiedzy, prestiżu i zasobów finansowych. Zaczynamy gonić systemy zachodnie, lecz odbywa się to bez niezbędnych nakładów finansowych (których brak osłabia z kolei istnienie 
konkurencyjnych mechanizmów finansowych), a systemy te, jak się wydaje, uciekają nam coraz szybciej, czego nie chcemy dostrzegać i na co nie potrafimy reagować. Ta sytuacja musi jak najszybciej ulec zmianie.

Zachodzące od dekady procesy umiędzynarodowienia polskiej nauki nazywamy jej dehermetyzacją. Rodzi ona nieznane przedtem napięcia, ponieważ szersze otwieranie się na świat stopniowo obala tradycyjne hierarchie akademickie. Pojawia się nieznany dotąd, a przynajmniej szerzej niedoceniany, wymiar funkcjonowania naukowego - wymiar międzynarodowy, stanowiący istotę funkcjonowania naukowego w Europie (a mniej ważny w tak centralnym dla świata systemie jak system amerykański z racji jego wielkości i położenia w sercu globalnej produkcji wiedzy). Polskie autorytety coraz silniej w ujęciu młodej kadry muszą dysponować legitymizacją płynącą z międzynarodowych kanałów transmisji wiedzy, wpływów i prestiżu. W sytuacji, w której rozhermetyzowywana na Europę i świat nauka polska jest oceniana w kontekście osiągnięć światowych i europejskich, polska hierarchia naukowych autorytetów w sposób konieczny ewoluuje i będzie ewoluować. Uszeregowanie w prestiżu naszej nauki będzie więc musiało być silniej powiązane z uszeregowaniem w prestiżu nauki europejskiej czy światowej. Dopiero wtedy tak na co dzień szeregowana i finansowana nauka polska nabierze cech nauki „centrum”, a nie „peryferii” (Antonowicz 2015).

Świat nauki jest pod względem hierarchizacji niezwykle okrutny, a zarazem niezwykle merytokratyczny i otwarty. Hierarchia autorytetów „centrum” opiera się na miejscu zajmowanym w nauce światowej - albo takie miejsce się zajmuje, albo nie. Nawet słabe miejsce w międzynarodowym obiegu naukowym jest lepsze (dla kadry, a także dla krajowej nauki i krajowych instytucji) niż żadne. Widać to najlepiej po strukturze wskaźników w międzynarodowych rankingach uczelni, w których liczą się przede wszystkim bardzo dobre publikacje (w globalnie definiowanych bardzo dobrych miejscach) oraz ich liczba przypadająca na zatrudnionego naukowca. Młode pokolenie już o tym doskonale wie, starsze pokolenie - w dużej mierze nie przyjmuje do siebie konsekwencji tych prostych (i uniwersalnych) reguł. Sama świadomość możliwości funkcjonowania w międzynarodowym obiegu naukowym oraz coraz większa konieczność spełniania nowych wymogów awansowych stopniowo zmieniają reguły gry naukowej w Polsce - przede wszystkim przez silne bodźce finansowe i konkurencyjność dostępu do niewielkich środków na badania naukowe. Podobnie jak w nauce europejskiej, zaczyna liczyć się nie publikacja, ale miejsce jej wydania; a następnie już nie samo wydanie, ale międzynarodowy oddźwięk na jej obecność w nauce, czyli kumulujący się przez lata poziom cytowalności.

Prestiż w nauce pochodzi przecież wyłącznie z osiągnięć naukowych (a nie dydaktycznych czy administracyjnych). Można się spodziewać, że w Europie zachodzić będzie dalsze różnicowanie profesji akademickiej, której mniejsza niż w poprzednich dekadach część będzie angażować się w badania naukowe, zazwyczaj 
prowadzone w sektorze publicznym szkolnictwa wyższego i finansowane przez państwo. Pośród przystosowań do zmieniających się warunków zewnętrznych w celu rozwijania się - uniwersytety muszą nieustannie próbować sprostać potrzebom naukowców, szczególnie odkąd różnica w dochodach między specjalistami zatrudnionymi w sektorze prywatnym a naukowcami zatrudnionymi na uniwersytetach jest coraz większa. Najlepiej radzące sobie segmenty klasy średniej (klasa kreatywna Richarda Floridy czy analitycy symboliczni Richarda B. Reicha) mają coraz mniej wspólnego z uniwersyteckimi profesorami, co dziś w wielu obszarach nauki rodzi ogromny problem zastępowalności akademickich pokoleń o podobnych aspiracjach, ambicjach i kompetencjach. Najlepsze umysły nie muszą już tak często wybierać pracy akademickiej jak jeszcze dwie czy trzy dekady temu. Inne są punkty odniesienia dla kreatywnej klasy średniej i inne są jej oczekiwania. Praca akademicka staje się coraz bardziej podobna do pracy korporacyjnej, a zarazem różni się od niej poziomem wynagrodzeń. Kiedy rosną wymagania, rośnie presja na wyniki, spadają gwarancje stałego zatrudnienia i wieloletniej kariery zawodowej, a zarazem relatywnie maleją wynagrodzenia i obszar indywidualnej wolności - atrakcyjność akademickiego miejsca pracy siłą rzeczy musi spadać. To nie tylko problem Polski, ale całego świata zachodniego.

Wydarzenia związane ze spodziewanym większym różnicowaniem kadry akademickiej (a zarazem jej podziałem na malejący segment posiadaczy i rosnący segment wykluczonych, czyli academic haves i academic have-nots, w różnym stopniu w różnych krajach) mogą istotnie zmienić charakter profesji akademickiej jako takiej, jeszcze bardziej zwiększać jej heterogeniczność i wywierać silny wpływ na tradycyjne relacje między kształceniem i badaniami na uniwersytetach europejskich. Analogiczne procesy po drugiej stronie Atlantyku, w modelu anglosaskim w wersji amerykańskiej, są już mocno zaawansowane i dokładnie przeanalizowane zarówno w literaturze badawczej, jak i w literaturze z obszaru polityki publicznej. Rosnąca konkurencyjność akademickiego miejsca pracy w powiązaniu z jego rosnącą, coraz bardziej systemową niestabilnością oraz malejącą atrakcyjnością finansową, jakiej tradycyjnie oczekiwała klasa średnia, powoduje spadek atrakcyjności całej profesji.

Tradycyjny kontrakt społeczny państwa z akademią oznaczał bowiem spory zakres wolności akademickiej, stosunkowo dużą wolność dysponowania własnym czasem, dużą stabilność zawodową i - z coraz większym trudem, ale jednak możliwy do utrzymania - materialny status klasy średniej. Nowy kontrakt oznacza zaś stopniowe wycofywanie się państwa ze wszystkich gwarantowanych dotąd, głównie w niepisany sposób (choćby profesurze) wymiarów pracy akademickiej: mniejszą wolność akademicką (tj. rosnący nacisk na stosowalny, a nie podstawowy charakter badań, a więc na naturę relacji: przedmiot badań - jego publiczne finansowanie), mniejszą stabilność zawodową, mniejszą możliwość dysponowania własnym czasem i niższy status materialny. Tradycyjne motywy prowadzenia 
badań - triada: curiosity, ribbon i gold, czyli naukowa ciekawość, akademickie zaszczyty i sfera materialna - odgrywają taką samą rolę jak w poprzednich dekadach, ale wszystkie, a zwłaszcza pierwszy i trzeci, podlegają zarazem systematycznym ograniczeniom.

Kadra akademicka w czasie kolejnej fali reform musi być świadoma procesów zewnętrznych względem szkolnictwa wyższego, a jednak ściśle związanych z jego przyszłością. Należą do nich m.in. zmieniające się w czasie uzasadnienia publicznego finansowania badań naukowych oraz ich priorytetowych obszarów (np. bio-info-techno vs. wszystkie pozostałe) i priorytetowych typów (np. stosowane vs. podstawowe); rosnąca konkurencja międzysektorowa o publiczne finansowanie, zwłaszcza w coraz bardziej starzejących się społeczeństwach; rewizja umowy społecznej między uniwersytetami a rządami, powiązanej z powojenną ekspansją nauki w Europie, w tym reformy państwa dobrobytu i wszystkich usług sektora publicznego; zmieniające się priorytety polityki naukowej (nauka korporacyjna vs. nauka akademicka); zmieniająca się społeczna percepcja użyteczności badań naukowych w gospodarce opartej na wiedzy; globalizacja i internacjonalizacja sektora badań akademickich oraz idei leżących u podstaw ich reformowania; zróżnicowana premia płacowa za wyższe wykształcenie (według obszarów studiów) we współczesnym świecie. Wszystkie te czynniki wywierają ogromny wpływ na obecny, a szczególnie przyszły rynek pracy akademickiej, w tym na jego ekspansję w niektórych obszarach i kurczenie się w innych. Bardziej gwałtowne i bardziej nieprzewidywalne zmiany w naturalnym otoczeniu europejskich uczelni, czyli w gospodarce, oznaczają z pewnością jeszcze mniej stabilny i jeszcze bardziej konkurencyjny rynek akademicki.

Sytuacja kadry akademickiej i jej perspektywy na przyszłość zmieniają się radykalnie w Europie, ale mamy nadzieję, że coraz większa będzie również powszechna świadomość, że za sukcesami systemów nauki i poszczególnych instytucji stoją konkretni ludzie, że naukowcy są w samym centrum przedsięwzięcia akademickiego i są w tym miejscu niezastępowalni. Kształcenie naukowca do etapu samodzielności jest ogromną społeczną inwestycją, którą jednak mogą łatwo zmarnować niesprzyjające warunki pracy czy przekonanie o niskiej atrakcyjności przyszłej kariery zawodowej. Kształcenie naukowca do poziomu doskonałości w skali europejskiej kosztuje najczęściej wiele milionów euro (wystarczy pod kątem sumy wcześniejszych grantów krajowych przejrzeć życiorysy naukowe europejskich laureatów konkursów grantowych dla zaawansowanych naukowców z ERC).

Pozytywne (lub nie) nastawienie kadry akademickiej na przyszłość, jej optymizm lub pesymizm, odnalezienie się (lub zagubienie) w wyłaniającym się, nowym systemie reguł gry akademickiej i wreszcie jej ocena możliwości, jakie otwiera (lub zamyka) profesja akademicka dzisiaj - są kluczem do powodzenia instytucji uniwersytetu w przyszłości, zarówno w Europie, jak i w Polsce. 
Nauka w każdym średniej wielkości kraju europejskim wymaga dziesiątków tysięcy naukowców mocno zaangażowanych w badania naukowe, z których 1/3 (czy 1/4) korzysta w najlepszych miejscach z dużych grantów krajowych; na podstawie grantów krajowych powiększa się krajowa elita badawcza, z której część funkcjonuje w ramach europejskich i globalnych elit naukowych, często ze wsparciem międzynarodowych środków na badania. Nauka ma strukturę merytokratycznej piramidy - każdy jej kolejny poziom pracuje na sukces wyższych poziomów, a wsparcie przez państwo niższych jej poziomów skutkuje krystalizowaniem się jej poziomów wyższych. Nie zgadzamy się tym samym z silnym w Polsce przekonaniem, że wystarczy jedynie „wspierać najlepszych” naukowców i finansować wybrane ogniska naukowej doskonałości, bowiem na sukces nauki w poszczególnych państwach europejskich pracują dziesiątki tysięcy naukowców, z czego szczyty krajowe osiąga tylko część z nich, a szczyty europejskie - już tylko tysiące. Dlatego niezbędne jest silne zróżnicowanie instytucji szkolnictwa wyższego - na badawcze, badawczo-kształcące i kształcące, co byłoby bolesnym, ale niezbędnym w systemie masowym zerwaniem z dziedzictwem uniwersytetu humboldtowskiego. Dziedzictwem, które w Polsce i tak od ponad dwóch dekad jest już tylko z trudem podtrzymywaną fikcją.

W kontekście polskich reform podkreślających rosnącą rolę publikacji międzynarodowych warto przypomnieć, że zwiększenie poziomu i intensywności współpracy międzynarodowej w badaniach naukowych jest najlepszą drogą prowadzącą do stopniowego zwiększania międzynarodowej widzialności krajowych wyników badawczych. Tylko intensywna, długoterminowa, konsekwentnie wspierana finansowo przez państwo (na poziomie instytucjonalnym i indywidualnym: dotacje statutowe i granty) współpraca naukowa może stopniowo zamieniać mechanizmy mertonowskiej „kumulacji strat” w mechanizmy „kumulacji przewag” w polskiej nauce. Krótko mówiąc: pierwsza liga europejska gra między sobą (co widać najlepiej po wynikach konkursów dla zaawansowanych naukowców w European Research Council z ostatnich 8 lat) - nie da się do niej wejść bez dużych, przemyślanych i strategicznie rozdysponowanych nakładów państwa (wzorem w naszym regionie mogą być Węgry). W najbardziej konkurencyjnym europejskim konkursie na badania, w którym wydano 10 mld euro (i planuje się wydać kolejnych 13 mld), Polska zdobyła ok. $30 \mathrm{mln}-21$ grantów na 5200 przyznanych. To systemowa porażka polskiej nauki i pocieszeniem nie może być tu jej aktualne 19. miejsce zajmowane w globalnej cyrkulacji produkcji wiedzy (według bazy Scopus).

Najpoważniejszym problemem związanym z umiędzynarodowieniem nauki w Polsce jest dziś wyraźnie niższa produktywność badawcza naukowców niezaangażowanych we współpracę międzynarodową (czyli prawie połowy kadry akademickiej) oraz szokująco wysoki odsetek naukowców w ogóle niepublikujących. Ostatnie reformy wyraźnie odwołują się do nowych mechanizmów umiędzynarodowienia (np. w ramach parametryzacji jednostek naukowych), ściśle wiążąc je 
z nowym, instytucjonalnym strumieniem finansowania, korygując i wprowadzając coraz bardziej restrykcyjne warunki dostępu do indywidualnego i coraz bardziej konkurencyjnego finansowania badawczego w ramach Narodowego Centrum Nauki, jak również zmieniając - na razie w teorii - warunki awansów naukowych i instytucjonalnych. We wszystkich trzech obszarach (parametryzacja, granty badawcze, ścieżka kariery akademickiej) umiędzynarodowienie badań jest ważne jak nigdy dotąd w historii polskiej nauki.

Polska nauka wymaga więc także przeglądu kadrowego, ponieważ ciężar kadry nieproduktywnej naukowo staje się nie do udźwignięcia przez system, co z jednej strony podtrzymuje jego nieefektywność, a z drugiej - uniemożliwia poważną dyskusję na temat wzrostu nakładów na badania.

Akademickie miejsca pracy na najlepszych polskich uczelniach (w przyszłości - zwłaszcza badawczych) to nie tradycyjne „miejsca pracy”, które należy - jak dzisiaj - „chronić”. Raczej nikomu w opartych na prestiżu naukowym systemach zachodnich nie przychodzi do głowy, aby chronić za wszelką cenę nieproduktywnych kolegów, nienadających się do nauki ani nauką specjalnie się niezajmujących, niezależnie od ich wieku i zajmowanego stanowiska. Nauka wymaga wciąż nowych ludzi, z których część się nie sprawdza, ale którym miejsca muszą ustępować ci, którzy znaleźli się w niej z przypadku. Polskie przypadki trwają często całe dekady, co musi rodzić frustrację tych, którzy tylko z tego powodu nie mają szans na wejście do systemu. „Chronione uczelniane miejsca pracy” to pojęcie, które całkowicie blokuje regularną wymianę naukowców w najlepszych segmentach systemu.

Kolejność zdarzeń powinna więc być następująca: pierwszy duży ruch w postaci reform wykonało państwo (w latach 2009-2011), wprowadzając nowe mechanizmy funkcjonowania nauki; kolejny ruch powinna wykonać wspólnota akademicka, dostosowując strukturę kadry do struktury znanej z najlepszych systemów zachodnioeuropejskich; a wtedy, miejmy nadzieję, kolejny ruch, wprowadzający wzrost nakładów na badania i szkolnictwo wyższe, znowu wykona państwo. Tylko taki cykl wzajemnych dostosowań sponsorowanych (nauka akademicka) i sponsorujących (państwo reprezentujące interesy społeczeństwa) może prowadzić do powstania nowego kontraktu społecznego wokół szkolnictwa wyższego, a zwłaszcza jego prestiżowych segmentów.

Młode pokolenie kadry akademickiej zaczyna rozumieć - a pomagają mu w tym bodźce grantowe i awansowe - że polski obieg naukowy musi być częścią obiegu światowego i że obecność w pierwszym nie prowadzi bezpośrednio do obecności w drugim. Obok niemal darwinistycznego okrucieństwa najbardziej prestiżowego globalnego obiegu publikacyjnego w nauce - z setek nadesłanych prac ukaże się tylko kilkanaście czy kilkadziesiąt - objawia on swoją otwartość: upraszczając i pomijając kwestie językowe (bo nie ma sensu dyskusja z oczywistą tezą, że światowa nauka to nauka prezentowana po angielsku), każdy naukowiec ma podobne szanse na publikację swoich prac w najlepszym obiegu. System podwójnych, śle- 
pych recenzji otwiera wszystkim możliwości, choć nie daje gwarancji publikacji. Nie miejsce tu na analizę całości globalnego systemu dystrybucji wyników badań naukowych, analizę miejsca czasopism amerykańskich w tym systemie, koncentracji własności czasopism czy postulatów otwartej nauki (Szadkowski 2015) - w praktyce młoda kadra coraz lepiej wie, gdzie publikują najlepsi w jej dziedzinie i gdzie ona sama z czasem powinna przynajmniej próbować publikować, o ile chce pracować w prestiżowych miejscach. Polska kadra akademicka również w tym sensie się rozwarstwia, że stwierdzenia dotyczące globalnego charakteru nauki, coraz bardziej oczywiste dla młodych, dla starszych nadal są niezrozumiałe, a nawet wrogie, ponieważ dehermetyzacja polskiej nauki równie systematycznie burzy stabilność dotychczasowych, najczęściej lokalnych hierarchii akademickich. Fundamenty tego nowego rozwarstwienia w nauce są czymś nowym dla polskiej wspólnoty akademickiej - nie można go przypisywać lokalnym upodobaniom czy krajowym rozgrywkom w sferze władzy akademickiej. Jest ono silnie powiązane z postępującą globalizacją nauki, z jej jawnie i tradycyjnie międzynarodowym charakterem, z naturą prestiżu w obiegu nauki i związanymi z nim systemami naukowego uznania. Powracając na koniec do nadchodzącej fali reform - będziemy je pilnie śledzić, być może także wspierać i współkształtować, ponieważ będą one decydować o naszej akademickiej przyszłości.

prof. dr hab. Marek Kwiek

\section{Podziękowania}

Wydanie tego numeru nie udałoby się bez wsparcia udzielonego przez Narodowe Centrum Nauki (NCN) w ramach projektu MAESTRO (Program Międzynarodowych Badań Porównawczych Szkolnictwa Wyższego DEC-2011/o2/A/HS6/o0183, 2012-2017) oraz przez Fundację na Rzecz Nauki Polskiej (FNP) w ramach projektu MISTRZ (subsydium profesorskie - umowa 5/2015, 2016-2018). Wyrażam niniejszym swoją głęboką wdzięczność obydwu instytucjom.

\section{Literatura}

Antonowicz, D. (2015). Między siła globalnych procesów a lokalną tradycją. Polskie szkolnictwo wyższe $w$ dobie przemian. Toruń: Wyd. Naukowe UMK.

Kwiek, M. (2015a). Uniwersytet $w$ dobie przemian. Instytucje $i$ kadra akademicka $w$ warunkach rosnacej konkurencji, Warszawa: Wyd. Naukowe PWN.

Kwiek, M. (2015b). Młoda kadra: różnice międzypokoleniowe w pracy naukowej i produktywności badawczej. Czym Polska różni się od Europy Zachodniej? Nauka. 3: 51-88.

Kwiek, M. (2015c). Nierówności w produkcji wiedzy naukowej - rola najbardziej produktywnych naukowców w 11 krajach europejskich. Nauka i Szkolnictwo Wyższe. 1(45): 269-308. 
Kwiek, M. (2015d). Umiędzynarodowienie badań naukowych. Polska kadra akademicka z perspektywy europejskiej. Nauka i Szkolnictwo Wyższe. 1(45): 39-74.

Kwiek, M. (2015e). Reformy uniwersytetów europejskich: państwo dobrobytu jako brakujący kontekst badań i polityki publicznej. Człowiek i Społeczeństwo. 39: 165-196.

Kwiek, M. (2015f). Podzielony uniwersytet. Od deinstytucjonalizacji do reinstytucjonalizacji misji badawczej polskich uczelni. Nauka i Szkolnictwo Wyższe. 2(46): 41-74.

Kwiek, M. (2015g). Międzypokoleniowa ruchliwość społeczna: szkolnictwo wyższe a drabina edukacyjna i zawodowa w Polsce. Nauka i Szkolnictwo Wyższe. 2(46): 183-213.

Szadkowski, K. (2015). Uniwersytet jako dobro wspólne. Podstawy krytycznych badań nad szkolnictwem wyższym. Warszawa: Wyd. Naukowe PWN.

CYTOWANIE: Kwiek, M. (2015). Słowo wstępne: W obliczu nadchodzącej fali reform szkolnictwa wyższego w Polsce. Argumentacja i wizja wspierająca najważniejsze kierunki zmian. Nauka i Szkolnictwo Wyższe. 2(46): 7-16. DOI:10.14746/nsw.2015.2.0. 